\title{
empleo de la calcita en el hormigón
}

(emploi de la calcite dans le béton)

ediforial

de sournal de la Construction de la Suisse Romande», año 31, núm. 20, octubre 1956, pág. 1189

Recientemente se ha realizado un estudio profundo con el fin de dëterminar y controlar los ensayos necesarios para conseguir un conocimiento neto de las propiedades de la calcita, como adición para el hormigón.

Las conclusiones establecidas son las siguientes:

1. El aumento de la resistencia de Ios morteros y hormigones, conseguido al sustituir una parte de la arena natural por calcita pulverizada, es debido a un fenómeno físico, destgnado con el nombre de "acción de relleno". En este aspecto, la calcita no parece poseer propledades más importantes que otras mezclas de minerales pulverizados. 
2. No parece existir ningún indicio de que se produzca ninguna reacción química entre la calcita y la pasta de cemento. La teoría de la formación de nuevos cristales de calclta no es más que una hipótesis.

3. In ciertos casos, la adición de calcita determina un crecimiento de la resistencia a clertos ataques (sulfatos). Sin embargo, esta caracteristica no es única de la calcita, pues también se da en ciertas formas naturales de carbonato cálcico.

4. La adición de calcita finamente pulverizada reduce siempre la resistencia al hielo y deshielo, de la misma forma que otras mezclas de materiales pulverizados. Es posible que pequeñas adiciones de calcita, pulverizada, no demasiado finamente, pueda elevar la resistencia al hielo, pero todavía queda por realizar la prueba correspondiente.

5. No es posible, actualmente, determinar si la durabilldad, en las zonas de marea, puede mejorarse de forma significativa mediante la adición de calcita en grano grueso o pulverizada. S. F. S. 